\title{
Religion and the Church in Geoffrey of Monmouth
}

\author{
Barry Lewis
}

Few authors inspire as many conflicting interpretations as Geoffrey of Monmouth. On one proposition, however, something close to a consensus reigns: Geoffrey of Monmouth wrote history in a manner that shows remarkable indifference toward religion and the institutional church. Antonia Gransden, in her fundamental survey of medieval English historical writing, says that "the tone of his work is predominantly secular" and even that he "abandoned the Christian intention of historical writing" and "had no moral, edificatory purpose", while J.S.P. Tatlock, author of what is still the fullest study of Geoffrey, speaks of a "highly intelligent, rational and worldly personality" who shows "almost no interest in monachism ... nor in miracles", nor indeed in "religion, theology, saints, popes, even ecclesiastics in general". Yet, even if these claims reflect a widely shared view, it is nonetheless startling that they should be made about a writer who lived in the first half of the 12th century. Some commentators find Geoffrey's work so divergent from the norms of earlier medieval historiography that they are reluctant to treat him as a historian at all. Gransden flatly describes him as "a romance writer masquerading as an historian". ${ }^{2}$ More cautiously, Matilda Bruckner names Geoffrey among those Latin historians who paved the way for romance by writing a secular-minded form of history "tending to pull away from the religious model (derived from Augustine and Orosius) that had viewed human history largely within the scheme of salvation". ${ }^{3}$

This Christian tradition of historiography, against which Geoffrey of Monmouth is said to have rebelled, had its origins in late antiquity in the works of Eusebius, Augustine, and Orosius. Leaving aside the important differences between these authors, their legacy may be summarized as follows. History had a clear beginning in Creation, and it would come to an equally clear end with the final Judgement. Everything that happened between those two points

1 A. Gransden, Historical Writing in England, c.550-c.1307, London, 1974, pp. 187, 204, 207; Tatlock, $L H B$, pp. 257, 446. I am grateful to Ben Guy for his comments on a draft of this article, and to Daniel Watson for references provided. The views expressed are my own.

2 Gransden, Historical Writing in England, c.550-c.1307, p. 202.

3 M.T. Bruckner, "The Shape of Romance in Medieval France", in R.L. Krueger (ed.), The Cambridge Companion to Medieval Romance, Cambridge, 200o, pp. 13-28, at p. 35. 
was worthy of examination solely for what it revealed of the unfolding of God's will, and events were to be interpreted in terms of sin, punishment, and redemption. Early medieval authors adapted this framework for writing the history of individual peoples by showing how each nation achieved membership of the universal Christian church. In this providential view of history, there was room for the exemplary function - the idea that history provided models of good behavior to be imitated and of bad behavior to be avoided - but the emphasis was on the unfolding of God's plan.

In different ways, all of Geoffrey of Monmouth's predecessors - Gildas, Bede, and the author of the Historia Brittonum - subscribed to this tradition by setting the history of Britain within the wider story of salvation. Geoffrey, according to much modern commentary, turned away from their preoccupation with providence. He was not a preacher, nor did he attempt a church history, and while the author of the Historia Brittonum chose to start from the creation of the world, Geoffrey's work opens with the pagan heroes of Troy. Yet beyond the mere consensus that Geoffrey wrote a new, more secular kind of history, opinions begin to diverge sharply. If his aim was not to expound the role of God in shaping events, what was it? Some have argued for political motives, often quite incompatible ones: either to endow the Anglo-Norman kingdom of England with a lengthy and glorious past, or to justify Norman rule over Wales, or alternatively to assert the ancient dignity of the Britons and their descendants, the Welsh, or else to advance the interests of those numerous Bretons who had crossed the Channel as part of the conquering Norman aristocracy. Others emphasize intellectual, literary, and personal motives, but these too are very varied: to make a career for himself by revolutionizing the tradition of English historiography, to disparage monastic values, even just to amuse himself at the expense of his readers. A particularly influential strain of criticism sees Geoffrey's rebellion as a philosophical one. His work, so it is argued, shows how history proceeds through the interaction of human desires and weaknesses with the caprices of blind fortune. Regimes and dynasties are intrinsically fragile and prone to failure and replacement by others. In Robert Hanning's phrase, Geoffrey chose to write a story of "great men on a great wheel". ${ }^{4}$ Siân Echard has questioned whether Geoffrey accepted that historical events reflected the workings of divine justice at all. ${ }^{5}$

4 R.W. Hanning, The Vision of History in Early Britain: From Gildas to Geoffrey of Monmouth, New York, 1966, p. 121.

5 S. Echard, Arthurian Narrative in the Latin Tradition (Cambridge Studies in Medieval Literature, 36), Cambridge, 1998, ch. 1 passim. 
So closely is medieval historiography bound to the providential model that Geoffrey of Monmouth's work can appear too anomalous to discuss within the boundaries of the genre. Those who see Geoffrey as a proto-romancer and precursor of Chrétien de Troyes set him within the context of the literature of the royal and aristocratic courts of the 12th century, courts that attracted authors who, like Geoffrey, were secular clerks rather than monks. Looking to the past for models of aristocratic self-definition, they turned to the pagan antiquity described so vividly in the Latin classics. Some of the earliest romances explored the values of courtly society through the adventures of Alexander and the events of the Trojan War. If medieval historians looked to the past to discern the will of God, authors of romances reimagined it in terms of the culture and values of their aristocratic audiences. Geoffrey might be seen as a transitional figure, writing the Latin prose of the historian but conveying the spirit of the romancer. Francis Ingledew has argued that Geoffrey expresses a new "genealogical construction of history" in the service of the Anglo-Norman aristocracy, who traced their roots literally back to Troy, as did the Britons: ${ }^{6}$ such a view would suggest that Virgil's Aeneid shaped Geoffrey's account of British origins more profoundly than the Old Testament.

$D G B$ is not, however, a romance. It is in Latin, and claims for itself the genre of history: Geoffrey famously cites Gildas and Bede as his predecessors, and William of Malmesbury, Henry of Huntingdon, and Caradog of Llancarfan as his colleagues. If we wish to discuss how, or even whether, his concept of history differs from theirs, then we will have to consider the role of God in Geoffrey's narrative and the respective importance of providence, chance, and human agency in shaping the flow of events. Each one of the interpretations which I have mentioned so far concedes that Geoffrey was detached from the concerns of providential history; some even suggest that he barely allowed any role to God in guiding events. In this chapter I shall scrutinize this proposition. I shall argue that is possible to go too far in secularizing Geoffrey of Monmouth. His work, like that of his predecessors, shows a strong interest in religious history and in the place of the Britons within the unfolding story of salvation, and he does not, in the end, emancipate himself from a providential view of events.

6 F. Ingledew, "The Book of Troy and the Genealogical Construction of History: The Case of Geoffrey of Monmouth's Historia regum Britanniae", Speculum 69:3 (1994), 665-704. 
The first four books of the $D G B$ are set in the pagan past. The British nation is traced back to Brutus, a great-grandson of Aeneas. Brutus is born in Italy but is exiled after he accidentally kills his father with an arrow. He visits Greece, Africa, and Aquitaine, winning battles and gaining supporters on the way. On an island called Leogetia he discovers a temple of Diana and receives from the goddess a prophecy that he will found a second Troy in an island in the ocean, that is, in Britain. Brutus and his followers duly land in Britain, clear it of the giants who were its only inhabitants, and found a kingdom. Brutus and his successors rule for many centuries. During this time, all of them are pagans and are presented as such; occasional synchronisms with biblical events remind us that this all happens long before the time of Christ. Geoffrey accepts the paganism of his characters without comment or explicit disapproval. Among the achievements of his British kings he notes the building of temples and the proper conduct of sacrifices. At least one king, Belinus, is cremated. The influence of classical texts is apparent in these early books, especially Virgil's Aeneid. Such texts provided ample sources for pagan ritual, so that Geoffrey was able to describe sacrifices in some detail, notably when Brutus and his companions worship Jupiter, Mercury, and Diana on Leogetia. ${ }^{7}$ In contrast, the burial of several of the kings within cities, and even in or near temples, is a medieval Christian conception, for in pagan times bodies were buried in cemeteries outside city walls and would have been regarded as a pollution in spaces consecrated to the gods. ${ }^{8}$ Geoffrey resembles other 12th-century authors in showing a strong tendency to view the pagan past as analogous in many respects to the Christian present. ${ }^{9}$ This extends to the occasional reference within these early chapters to God or to a single creator. ${ }^{10}$ Similarly, pagan figures are judged by the same moral standards as contemporary ones. So Geoffrey's good kings are notable for pursuing justice, passing equitable laws, making peace between disputants, laying out roads, and founding cities

$7 \quad D G B$, i.16.28o-315. For discussion, see Tatlock, $L H B$, p. 261.

8 Tatlock, $L H B$, p. 26o. An example is Dunuallo Molmutius, buried in Trinovantum "prope templum Concordiae", "near the temple of Harmony" ( $D G B$, ii.34.336-37).

9 On this phenomenon see H. Phillips, "Medieval Classical Romances: The Perils of Inheritance", in R. Field, P. Hardman, and M. Sweeney (eds.), Christianity and Romance in Medieval England, Cambridge, 2010, pp. 13-25.

$10 \quad D G B$, iii.41.134, 57.76, and iv.63.255-57. J. Marenbon, Pagans and Philosophers: The Problem of Paganism from Augustine to Leibnitz, Princeton and Oxford, 2015, p. 70 has characterized Geoffrey's treatment of paganism, like that in many romances, as "incidental": that is, he does not raise any of the theological and moral difficulties that Marenbon gathers under the heading "the Problem of Paganism". 
and temples. Bad kings engage in sodomy and are ripped to pieces by wolves, or practice necromancy and fall to their deaths. ${ }^{11}$ Even in these cases, Geoffrey avoids explicit moralizing, simply allowing the fate that befell these kings to speak for itself. Of course, the pagan kings of Britain lived in the period before Christ and could not know the truth, though they might pursue natural justice; Marcia, queen to the equitable king Guithelinus, for instance, creates her "Marcian Law" proprio ingenio, "through her own devising".12 This allows their achievements to be safely claimed for the British nation: the founding of famous cities such as London and Leicester, the development of roads, even the sanctuary rights of churches, which are supposed to derive from similar rights assigned to the pagan temples by King Dunuallo. ${ }^{13}$ Only with the conversion of the Britons to Christianity does a clearly negative view of paganism emerge.

\section{Conversion to Christianity, and the Establishment of a British Church}

At the end of Book IIII, at a date still deep within the period of Roman domination, the Britons convert to Christianity. Learning of the miracles being performed by Christians in other lands, the British king Lucius writes to Pope Eleutherius asking for a mission. In response, the pope sends two teachers named Faganus and Duvianus, who baptize both the king and his people. The pagan temples are turned into churches. Geoffrey asserts that there was already a religious hierarchy in pagan Britain, consisting of twenty-eight flamines overseen by three archiflamines whose seats were at London, York, and Caerleon in Wales. In classical times, a flamen was a priest who served a particular pagan deity, but here he is a figure who has authority over lesser religious functionaries (described as "the remaining spiritual advisors and temple-servants") and thus foreshadows the role of the Christian bishop. ${ }^{14}$ The archiflamen (not a classical term) in turn resembles a Christian archbishop. Indeed, upon conversion each flamen is replaced by a bishop, and each archiflamen by an archbishop. Once this arrangement has received the pope's approval, King Lucius further demonstrates his piety by handing over the landed wealth of the temples to the new churches.

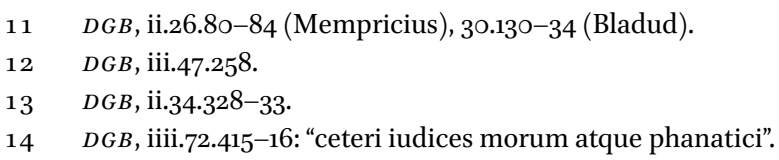


Geoffrey's account of the conversion of the Britons is a developed form of the Lucius legend. The story that a British king called Lucius wrote a letter to the pope first appeared in the collection of short papal biographies known as the Book of the Popes (Liber Pontificalis), from where it was taken up in the 8 th century by Bede. ${ }^{15}$ By the early gth century the story had found its way to Wales: it appears in the Historia Brittonum of 829 or 830 , probably drawn from Bede. ${ }^{16}$ As is now well established, the real Lucius was a king of Edessa in Syria, and the connection with Britain is spurious. ${ }^{17}$ The Lucius legend filled a gap in the historiography of the Britons by offering a legend of conversion on the typical medieval model: a top-down, king- and missionary-centered account in which the ruler's conversion is followed naturally by the conversion of his whole realm and the founding of churches. It is the model familiar from Bede's description of the conversion of the English kingdoms. Bede, however, had allowed Lucius a mere few lines, dismissed the Britons as defective Christians, and devoted the rest of his work to the new, orthodox church of the English. Geoffrey provides the entire British people with a church with claims to roots older than those of its English supplanter and a hierarchy more venerable than anything that derived from the mission of Augustine to Kent in 597.

The Lucian mission secured the claim of the British church to antiquity and to Roman orthodoxy. Geoffrey, though, was concerned with more than these requirements: he wanted to reconstruct the organization of the ancient British church. It has been shown that his source for the older pagan hierarchy of flamines and archiflamines and their replacement by Christian bishoprics was probably the 9th-century Pseudo-Isidorian Decretals, mediated through some text of canon law. ${ }^{18}$ Such an idea would interact powerfully with Geoffrey's own interest in ancient British geography. Throughout the $D G B$, Geoffrey attempts to reverse what he saw as the developments since the English conquests, so as to return to a presumed earlier dispensation. Thus, places with obvious

15 Bede, Ecclesiastical History i.4 and v.24, ed. and trans. B. Colgrave and R.A.B. Mynors, Bede's Ecclesiastical History of the English People, Oxford, 1969, rev. ed., Oxford, 1991, pp. 24-25 and 562-63, and On the Reckoning of Time lxvi.331, ll. 1164-65, ed. C.W. Jones, Bedae Venerabilis opera, vi: Opera didascalia 2, Turnhout, 1977, pp. 239-545, at p. 501.

16 Historia Brittonum §22, ed. Faral, LLA, vol. 3, pp. 2-62, at p. 19; D.N. Dumville, "Historia Brittonum: An Insular History from the Carolingian Age", in A. Scharer and G. Scheibelreiter (eds.), Historiographie im frühen Mittelalter, Wien, 1994, pp. 406-34, at pp. 432-44, discusses the likely influence of Bede over the Historia Brittonum, though not this passage.

17 A. Harnack, "Der Brief des britischen Königs Lucius an den Papst Eleutherus", Sitzungsberichte der königlich-preussischen Akademie der Wissenschaften (1904), 909-16.

18 E. Jones, "Geoffrey of Monmouth's Account of the Establishment of Episcopacy in Britain", JEGP 40 (1941), 36o-63; S. Williams, "Geoffrey of Monmouth and the Canon Law", Speculum 27:2 (1952), 184-9o. 
upstanding Roman remains, but which were of little consequence in Geoffrey's time, could be rehabilitated as great centers of ancient British life: Silchester and Caerleon are examples. Another key source was the list of the 28 cities of Britain, found in Historia Brittonum. ${ }^{19}$ That bishoprics should be established in major towns was a well-known principle in Geoffrey's time. By combining this idea with the evidence for earlier cities, both written and archaeological, Geoffrey was able to locate the ancient bishoprics of the Britons in centers where no bishop sat in his day. The idea that the metropolitans should be in London and York was derived from Bede. ${ }^{20}$ Like the rest of the geography of the $D G B$, Geoffrey's church hierarchy appears at once familiar and strange. Its foreignness to the actual hierarchy of the 12th century subtly undermines the authority of the English dispensation.

A further striking feature is the third province, covering Wales. The existence of such a province was a matter of lively dispute in Geoffrey's time. The see of St Davids, in south-west Wales, had a long-standing claim to lead a separate Welsh province. It was a central argument of the Life of St David, composed by Rhygyfarch in the 1080s or 109os, that David had been elevated to an archbishopric, either by the Patriarch of Jerusalem, or at a famous synod held at Llanddewibrefi in mid-Wales, at which David preached against the Pelagian heretics and was acknowledged to be head of the British church. ${ }^{21}$ The first Norman bishop of St Davids, Bernard (1115-48), made a determined effort to secure recognition as metropolitan of a Welsh province. His efforts were resisted, however, by the south-eastern Welsh see of Llandaff. A Llandaff text, De primo statu Landavensis ecclesie ("On the First Condition of the Church of Llandaff"), written probably in the 112os, insisted that Llandaff's first bishop, Dubricius (Welsh Dyfrig), ruled a province extending over all of South Wales. ${ }^{22}$

19 Historia Brittonum §66a, ed. Faral, LLA, vol. 3, pp. 57-58.

20 Bede, Ecclesiastical History i.29, ed. and trans. Colgrave and Mynors, pp. 104-07. These were the locations originally selected by Pope Gregory, though political realities led to a different arrangement.

21 See Rhygyfarch ap Sulien, Life of St David §46, ed. and trans. R. Sharpe and J.R. Davies, "Rhygyfarch's Life of St David", in J.W. Evans and J.M. Wooding (eds.), St David of Wales: Cult, Church and Nation, Woodbridge, 2007, pp. 107-55, at pp. 140-41, for the patriarch making David an archbishop, but there are signs that this is a clumsy alteration from Rhygyfarch's earlier version in which he was merely made a bishop, cf. §49, so that the granting of the archbishopric was reserved for the Synod of Brefi (\$53); this better suits the structure of the Life, which presents the synod as the climax of his career.

22 De primo statu Landavensis ecclesie, ed. J.G. Evans and J. Rhŷs, The Text of the Book of Llan Dâv: Reproduced from the Gwysaney Manuscript, Oxford, 1893, pp. 68-71, at p. 69. For the date, see W. Davies, "Liber Landavensis: its Construction and Credibility", EHR 88 (1973), $335^{-51}$, at pp. 338-39. 
Further, and very powerful, opposition came from Canterbury, which claimed the Welsh sees for itself. In the end, it would be Canterbury that emerged as the victor, terminating hopes for a separate Welsh province, but that outcome was far from settled when Geoffrey wrote.

If the Welsh province was an idea current in Geoffrey's time, his decision to place its see in Caerleon was definitely not. Why did Geoffrey make such a drastic intervention in the ecclesiastical history of Wales? No source is known, but Shafer Williams pointed out that texts of canon law, such as undoubtedly supplied the pseudo-historical terms flamen and archiflamen, were often accompanied by lists of bishops' sees. ${ }^{23}$ It is conceivable that, if Geoffrey encountered such a list, it may have contained a name bearing some resemblance to Urbs Legionum (Caerleon). On the other hand, Geoffrey had already attached great importance to Caerleon during the pagan period, and famously he would also choose it as the location of Arthur's magnificent feast, the culmination of his reign. ${ }^{24}$ The place undoubtedly mattered greatly to Geoffrey. John Gillingham has argued that he had an eye on political developments in south-east Wales, especially after the death of Henry I; in 1136 a local Welsh dynasty captured Caerleon and re-established Welsh power in a region that had seemed lost to Anglo-Norman encroachment. ${ }^{25}$ This may well have been a factor, though it is plausible that he had already been led to ponder on the place by the remarkable upstanding Roman remains, which he mentions ("in Caerleon, whose site beside the river Usk in Glamorgan is marked by ancient walls and buildings"). ${ }^{26}$ Add to this the fact that Urbs Legionum is one of the very few places mentioned by Gildas, in connection with the martyrdom of SS Julius and Aaron, and the temptation to make it a place of major importance may have been great. ${ }^{27}$ As a choice, it is quite consistent with Geoffrey's general use of textual and archaeological evidence to redraw the map of ancient Britain.

23 S. Williams, "Geoffrey of Monmouth", pp. 188-89, n. 17.

$24 D G B$, iii.44.218-23 and ix.156-62.

25 J. Gillingham, "The Context and Purposes of Geoffrey of Monmouth's History of the Kings of Britain", Anglo-Norman Studies 13 (1990), 99-118 (repr. in id. (ed.), The English in the Twelfth Century: Imperialism, National Identity and Political Values, Woodbridge, 20oo, pp. 19-39, at pp. 35-36).

$26 D G B$, iiii.72.419-21: "in Vrbe Legionum, quam super Oscam fluuium in Glamorgantia ueteres muri et aedificia sitam fuisse testantur".

27 Gildas, The Ruin of Britain i.1o, ed. and trans. M. Winterbottom, Gildas: The Ruin of Britain and Other Works (Arthurian Period Sources, 7), Chichester, 1978, p. 92. In DGB, ix.156.31822 these two saints are the dedicatees of two magnificent churches at Caerleon. 
Christopher Brooke viewed the choice of Caerleon as so bizarre as to suggest that Geoffrey was deliberately mocking both St Davids and Llandaff. ${ }^{28}$ From our viewpoint the choice is indeed historically inaccurate, but we have seen that Geoffrey had his reasons. Nothing suggests that Caerleon was chosen to slight any other place. Llandaff, it is true, was bound to suffer in comparison because it was too near to Caerleon, and too lacking in obvious Roman credentials, to be imagined as a bishop's seat in its own right. Hence Geoffrey appropriated its founder-saint, Dyfrig, to be his archbishop of Caerleon, and demoted the other important Llandaff saint, Teilo, from a bishop to illustris presbyter Landaviae, "distinguished priest of Llandaff". 29 St Davids, on the other hand, could have found little in the $D G B$ to complain about. It is described very positively as David's favorite monastery, founded by no less a figure than St Patrick, while David too receives lavish praise. ${ }^{30}$ Moreover, the $P M$ indicates that St Davids inherited the glorious primatial tradition that Geoffrey created for Caerleon. ${ }^{31}$ Accepting these ideas would compel considerable, and no doubt painful, surgery to St Davids' own traditions, as we shall see presently, but there is no case for saying that the $D G B$ sets out to denigrate St Davids or to cast doubt on its right to lead a Welsh province. The essence of Geoffrey's claim is that the British church was much older and more venerable than the English one, and that led him to trace its structures back far earlier than the 6th-century David. The geography of Geoffrey's British church is not, I suggest, a challenge to any of the Welsh churches of the day. It is a challenge to Bede and to the English viewpoint that he represented.

Geoffrey's Conversion Story in the Light of Other 12th-Century Versions

Thus far it has been assumed that Geoffrey's account of the British church was his own creation. I believe this to be essentially correct, but the Lucius legend was topical in Geoffrey's time, so the question of what he may have drawn from the work of others must be addressed. Bede simply stated that Lucius

28 C.N.L. Brooke, The Church and the Welsh Border in the Central Middle Ages, ed. D.N. Dumville (Studies in Celtic History, 8), Woodbridge, 1986, p. 24.

$29 D G B$, ix.158.407-08. Note, though, that Teilo is treated with great respect and is made archbishop of Dol in Brittany, an idea that is implied in the Book of Llandaff Life of St Teilo, ed. J.G. Evans and J. Rhŷs, The Text of the Book of Llan Dâv: Reproduced from the Gwysaney Manuscript, Oxford, 1893, pp. 97-117, at p. 112, ll. 5-6.

$3^{\circ} \quad D G B$, ix.158.405-o6 (on David); xi.179.90-93 (on St Davids).

$31 \quad D G B$, vii.112.48-49. 
obtained what he had requested, but 12th-century writers add that a mission was sent from Rome to Britain and are interested in the names and activities of the missionaries. The relations between the various accounts have proved to be contentious. Here the question is whether Geoffrey responded to Bede alone or whether he had seen more recent versions of the story.

One of these new versions is given by William of Malmesbury in his The Early History of Glastonbury (c.1129). Unfortunately, the Early History was heavily interpolated during the 13th century, making it difficult to be certain how much of the account is William's own, but an excerpt added to some manuscripts of his Deeds of the English Kings allows us to be fairly certain of his original wording, in this section at least. ${ }^{32}$ William makes no mention of a church hierarchy: his only interest is in the belief that the missionaries sent to Lucius founded the first church at Glastonbury, on account of which their fame shall endure, even though the passage of time has carried away their names. This absence of names suggests that the tale was still very much under development when William of Malmesbury wrote, for the other versions are not shy to name the men in question. There is nothing in William's account which suggests that Geoffrey drew on it in particular.

A second account forms the opening section of the anonymous De primo statu Landavensis ecclesie, mentioned earlier. ${ }^{33}$ This tract from Llandaff names the missionaries as Elvanus and Meduuinus and insists that they were Britons sent to Rome as part of Lucius's original delegation. Unlike William of Malmesbury, the author of the De primo statu does not explicitly link the missionaries to the church on whose behalf he was writing. Nevertheless, Medwin may be associated with Llanfedw, near Llandaff, though Elfan has not been identified..$^{34}$ The De primo statu employs the Lucius story as a kind of preamble to its main matter, which is an account of the later mission of St Germanus of Auxerre and St Lupus of Troyes to Britain in 429 in order to combat the Pelagian heresy. It is to St Germanus, not the earlier Lucian mission, that Llandaff and

32 A reconstruction of William's original wording is given in William of Malmesbury, The Early History of Glastonbury, ed. J. Scott, The Early History of Glastonbury: An Edition, Translation and Study of William of Malmesbury's De Antiquitate Glastonie Ecclesie, Woodbridge, 1981, p. 168. For the much expanded later text see ibid., pp. 46-51; parts of this derive from Geoffrey.

33 De primo statu Landavensis ecclesie, ed. Evans and Rhŷs, p. 68.

34 Early attestations of Llanfedw, e.g. Landivedon (1281), seem to contain the hypocoristic element ty-, thus suggesting that the rest is a saint's name rather than the common noun bedw "birch trees". See the Melville Richards archive of Welsh place-names, Cronfa Ddata Enwau Lleoedd: Archif Melville Richards [Place-name database: the Melville Richards archive], <http://www.e-gymraeg.co.uk/enwaulleoedd/amr> (accessed 27 March 2017), s.v. Llanfedw. 
its privileges are traced. Even so, the Lucian preamble conveys the idea that British Christianity had a continuous history from ancient times, a theme which is developed far more explicitly by Geoffrey. It also broaches the idea of a church hierarchy, but it offers no detail beyond the bare statement that an ecclesiasticum ordinem, "ecclesiastical structure", was founded and bishops ordained; it lacks any mention of Geoffrey's flamines or archiflamines. In both Geoffrey and the De primo statu the number of missionaries is two, a figure which does not appear in the uninterpolated Early History of Glastonbury. This suggests some kind of link between Geoffrey and the Llandaff document. Bafflingly, the names of the missionaries are different, and yet those given by Geoffrey still suggest Llandaff influence. His Faganus is certainly Ffagan of St Fagan's, a parish that borders on Llandaff, and Duvianus is in all likelihood Dyfan of Merthyr Dyfan, a few miles to the south-west. It is hard to see these names as other than chosen in the interests of Llandaff, yet in Llandaff's own account, as we have just seen, the missionaries are called Medwin and Elfan. ${ }^{35}$ There is no obvious reason why Geoffrey should have altered the names, so the conclusion suggests itself that he was following a different source, not now extant, but which should also have come from Llandaff. Why there should be two different sets of names for the Lucian missionaries, both apparently invented to suit Llandaff, remains a mystery.

Yet another version of the Lucius legend is found in a letter apparently sent by the chapter of the cathedral of St Davids to Pope Honorius II (1124-30). ${ }^{36}$ The letter sets out the claims of St Davids to be an archbishopric and the metropolitan see of Wales. It calls the Lucian missionaries Faganus and Duvianus, as in Geoffrey. Unlike Geoffrey, it identifies the third, Welsh archbishopric with St Davids, a decision which leads the writer into considerable historical difficulties. Nevertheless, the letter's insistence that St Davids was founded during the Lucian mission establishes primacy over Llandaff which, as we saw above, did not make such a grandiose claim. To judge by the dates of Pope Honorius, this letter precedes Geoffrey by some years. Indeed, it could be the lost source followed by Geoffrey; this was the conclusion accepted by Christopher Brooke

35 Neither St Fagan's nor Merthyr Dyfan is attested until after Geoffrey's time, so the possibility must be admitted that they took their names from Geoffrey; in which case, Geoffrey's source is wholly obscure. However, Merthyr Dyfan belongs to a type of name that was obsolescent in the 12th century (D. Parsons, Martyrs and Memorials: Merthyr Place-Names and the Church in Early Wales, Aberystwyth, 2013, p. 40), and is most unlikely to be a late coinage.

$3^{6}$ Gerald of Wales, Invectives ii.1o, ed. W.S. Davies, "De Invectionibus", Y Cymmrodor 30 (1920), 1-248, at pp. 143-46. 
and later by John Reuben Davies. ${ }^{37}$ The implications are profound, for the letter contains many more similarities to Geoffrey's account, such as the story of the replacement of the pagan hierarchy and the idea that there were three archbishoprics. If Geoffrey took from the letter not only the minor detail of Faganus and Duvianus, but these important ideas as well, then most of his vision of the early British church would have to be seen as a St Davids invention.

There are compelling reasons for rejecting this theory. The letter is extant only in a collection made by Gerald of Wales in the early $13^{\text {th }}$ century. Why would a writer, working in the 1120 s in the interests of St Davids, choose the names Faganus and Duvianus which take us so infallibly back to Llandaff? The likelihood must be that the author found them in an existing source and felt compelled to use them. That points to Llandaff - or to Geoffrey. It is possible that the St Davids writer used the same, lost Llandaff source that, I have argued above, lies behind Geoffrey's account. However, further problems in the letter point to Geoffrey himself as the source. In Geoffrey's scheme, the Welsh archbishopric lay at Caerleon and only later passed to St Davids; David himself was archbishop of Caerleon, not St Davids, which was merely a favorite monastery of his, and he was himself preceded in the archbishopric by St Dyfrig. In contrast, St Davids' tradition, as seen in Rhygyfarch's Life of St David, was that David first founded his church and that it was later elevated to the status of an archbishopric on account of David's stellar performance at the Synod of Brefi. The letter-writer has sacrificed these cherished ideas in order to accommodate what Geoffrey says. He does not mention Caerleon by name nor refer to the transfer of the archbishopric. That allows him to imply that St Davids was the seat of the Welsh archbishops from the beginning and to accommodate the idea that Dyfrig was David's predecessor, but it forces him to abandon the idea that David founded St Davids. ${ }^{38}$ The whole story of the Synod of Brefi is also lost since it could not sit with the idea of a much older, Lucian archbishopric. The writer has done a heroic job of absorbing the $D G B$ and turning it to his own purposes, but the costs were severe. When we see that the letter explicitly refers to the Welsh archbishopric as the third in textu historiarum, it

37 Brooke, The Church and the Welsh Border, p. 22 and n. 26; J.R. Davies, The Book of Llandaf and the Norman Church in Wales, Woodbridge, 2003, p. 110. Davies has become less sure in "Cathedrals and the Cult of Saints in Eleventh- and Twelfth-Century Wales", in P. Dalton, C. Insley, and L.J. Wilkinson (eds.), Cathedrals, Communities and Conflict in the Anglo-Norman World, Woodbridge, 2011, pp. 99-115, at pp. 102-03, esp. n. 103, where he cautiously acknowledges that the letter is indebted to Geoffrey.

38 Gerald of Wales, Invectives ii.10, ed. Davies, p. 143: "Ad cuius sedem ... beatus Dauid ... legitur fuisse archipresul consecratus", "to which see ... we read that the blessed David ... was consecrated archbishop". 
is hard to avoid the conclusion that the author is citing Geoffrey's book, which does indeed name Caerleon in third place. ${ }^{39}$ It is conceivable that parts of Geoffrey's work were already circulating in the late 1120 s, in time to be used by the writer of the letter to Honorius; certainly Geoffrey's views on the status of Caerleon must have been formed by the time he came to write the $P M$, since it is mentioned in it, and the prophecies circulated a few years before $D G B$ was finished around 1138. More likely, however, is that the letter as we have it is a later product, and suspicion must fall on Gerald of Wales. ${ }^{40}$

The theory that the St Davids letter was Geoffrey's main source throughout his account of the conversion must be rejected. It seems rather that he used a version of the Lucius legend from Llandaff, containing the names Faganus and Duvianus, but otherwise probably similar to the existing De primo statu Landavensis ecclesie, hence the importance of St Dyfrig in Geoffrey's vision. The hierarchy, especially the three metropolitan sees, was his own creation, for the same text shows that Llandaff never evolved a clear sense of itself at the head of a Welsh province; that was a St Davids concept, but one which Geoffrey transformed following his own priorities. Geoffrey, too, was the first author explicitly to trace the Welsh hierarchy as far back as the time of King Lucius. What emerges, then, is that Geoffrey was neither a passive recipient of the church history written by his contemporaries, nor an irreligious joker intent on subverting it. Rather, he had a coherent vision of the early British church, formed by reading his sources in a spirit of opposition, or at least oneupmanship, with regard to the English church. His vision was serious enough to persuade a later advocate of St Davids to recast the traditions of his church as profoundly as we see in the so-called "letter to Pope Honorius".

39 Thus I would translate in textu historiarum as "in the text of the Histories", cf. $D G B$, ix.156.321-22, 332-33: "terciam metropolitanam sedem Britanniae habebat ... Trium etiam metropolitanarum sedium archipraesules, Lundoniensis uidelicet atque Eboracensis nec non et ex Vrbe Legionum Dubricius", "Britain had three metropolitan sees ... also the three archbishops of the metropolitan sees, namely, of London and York, and also from Caerleon, Dubricius" (translation adapted from Wright). See also St Davids Episcopal Acta, 1085-1280, ed. J. Barrow, Cardiff, 1998, p. 4, who also regards the letter as dependent on Geoffrey.

40 This is denied by Brooke, The Church and the Welsh Border, p. 22, n. 26. He acknowledges that the letter diverges greatly from other St Davids sources, but does not account for the divergence. I suggest that the writer was assimilating a rival version that was too influential to ignore. That is a fair description of the status of Geoffrey's work $c .1200$, but it is doubtful whether it would be the case before the full publication of the $D G B$. Gerald's use of Geoffrey is well-attested, notably in the account of Welsh Christian origins which he wrote himself (Gerald of Wales, Invectives ii.1, ed. Davies, pp. 130-35). 
The unbroken tradition of the British church is a major theme of Geoffrey's $D G B$. Repeatedly, at points in his story where his sources raised uncomfortable hints of discontinuity, Geoffrey took pains to smooth over the cracks. Recasting Gildas's account of the Diocletianic persecution, he attributes the blame for carrying out the persecution in Britain to a Roman official, Maximianus Herculius, implicitly exonerating the British king Asclepiodotus who was reigning at the time. ${ }^{41}$ Another awkward moment was the mission of Germanus and Lupus, who came to Britain to combat the Pelagian heresy in 429. The mission occupies four chapters in Bede, but Geoffrey ruthlessly disposes of it in a few lines, incidentally shifting part of the blame for the poor state of British Christianity onto the Saxon pagans. ${ }^{42}$

It is, however, in Geoffrey's long account of the battle for supremacy between the Britons and the Saxon invaders that the unbroken thread of British Christianity is to be seen most clearly. From the outset, great emphasis is laid on the pagan religion of the newcomers. The moment when the British king Vortigern learns that they are not Christians is described vividly: Hengist states that "Mercury" led them to Britain, and Vortigern, hearing the name, lifts up his head with sudden attention and asks what religion they follow. On learning that they worship many gods, and Mercury or Woden above all, he says: "Your faith, or rather faithlessness, makes me truly sorry. Your coming, however, fills me with joy, since God or some other has brought you at an opportune time for my needs." ${ }^{33}$ Hengist, by his own reckoning, had been guided to Britain by his god Mercury or Woden. Vortigern doubts whether Mercury is a god or rather some other kind of power (siue deus, siue alius - I would translate deus as "a god", without capitalization, here) yet he eagerly accepts the help of the pagans, hard pressed as he is by Pictish attacks and by the threat of invasion from Brittany. Vortigern is not a pagan himself: of that Geoffrey leaves no doubt. He is, rather, a Christian who deliberately allies himself with a pagan under the control of demonic forces. Already Vortigern has shown great wickedness, first in elevating the monk Constans to the throne against his monastic vows, and then in having Constans murdered and usurping the throne himself. Allying himself with Hengist, even while acknowledging the possibility that a demonic

\footnotetext{
$41 \quad D G B$, v.77.103ff.

$42 D G B$, vi.1o1; Bede, Ecclesiastical History i.17-22, ed. and trans. Colgrave and Mynors, pp. 54-69.

$43 D G B$, vi.98.285-87: "De credulitate uestra, quae pocius incredulitas dici potest, uehementer doleo. De aduentu autem uestro gaudeo, quia in congruo tempore uos necessitati meae siue deus siue alius optulit."
} 
being lay behind his coming to Britain, marks a further step down into depravity. Yet Geoffrey sets the final descent into evil in Vortigern's sexual desire for Hengist's daughter, Ronwein. Again, Geoffrey leaves no room for ambiguity:

Vortigern became drunk on various kinds of liquor and, as Satan entered into his heart, asked her father for the girl he loved. Satan, I repeat, had entered into his heart, for despite being a Christian he wanted to sleep with a pagan woman. ${ }^{44}$

Through Vortigern, a usurper who was never accepted as legitimate by a consensus of the Britons, but who tricked his way to the throne under a cloud of suspicion, the pagans are admitted into the Christian land of Britain. It is made clear that they could never have fought their way in against the united resistance of the Britons, neither were they accepted by the British people. Vortigern's role in the story is to be the tool of Satan whose sinful weakness explains how God's people came to be led astray in this way. It is a view already expressed in the gth-century Historia Brittonum, to which Geoffrey's portrait of Vortigern is heavily indebted, but Geoffrey has enlarged on Vortigern's downward descent into evil. ${ }^{45}$

The subsequent struggle between the Britons and the Saxons is cast in terms both patriotic and religious, and amounts at times to holy war. The first leader of the British resistance is Vortigern's own son, Vortimer. He almost succeeds in expelling the Saxons entirely, but again the devil himself intervenes to cut short his success. The next deliverer, Aurelius Ambrosius, laments the fact that the Saxons have "destroyed our holy churches and wiped out the Christian faith almost from shore to shore". ${ }^{46}$ Repeatedly, the victory of the Saxons is postponed. Vortimer restores the churches of Britain. Aurelius restores them again. The greatest of all the British leaders is, of course, Arthur. Before his great victory at Badon, Arthur himself assures his men that they will be victorious through the aid of Christ. Then Archbishop Dubricius addresses the army, employing all the rhetoric of the Crusade. Death in battle against pagans is no death, for it brings certainty of eternal life: such martyrdom washes away

$44 D G B$, vi.10o.357-6o: "Vortigernus autem, diuerso genere potus inebriatus, intrante Sathana in corde suo, amauit puellam et postulauit eam a patre suo. Intrauerat, inquam, Sathanas in corde suo quia cum Christianus esset cum pagana coire desiderabat."

45 Cf. Historia Brittonum $\$ 37$, ed. Faral, LLA, vol. 3, p. 29: "intravit Satanas in corde Guorthigirni", "Satan entered into Vortigern's heart."

$46 D G B$, viii.119.49-50: "sacras ecclesias destruxit, et Christianitatem fere a mari usque ad mare deleuit." 
all sins. ${ }^{47}$ Now Arthur arms himself with his shield, on which is painted an image of the Virgin Mary, "to keep her memory always before his eyes". ${ }^{48}$ Hard pressed at the crisis of the battle, Arthur triumphs when he calls out the name of the Virgin. He is the third, following Vortimer and Aurelius, to restore the churches of Britain after they have been devastated by the pagans.

As is the case in much other literature of the time, hatred of paganism does not preclude respect for the prowess and chivalry of the pagans. Often the Saxons are depicted as fighting bravely. Yet this merely magnifies all the more the Christians who vanquish them. Only during the reign of the disastrous tyrant Kareticus do the Saxons, aided by the African king Gormundus, finally overrun England and send the archbishops of London and York fleeing into Wales, Cornwall, and Brittany with the relics of their saints. Even then continuity is preserved in those marginal regions ${ }^{49}$ and there is to be one final flourish of British rule, under Caduallo and Cadualadrus, before the end.

The advent of Christianity among the Saxons was a moment fraught with difficulty for Geoffrey. Thus far, his treatment of the Saxons could follow familiar lines. They could either be dismissed as utter barbarians, or treated as individual men of honor and courage and as worthy opponents of the Britons, but still ultimately damned to hell. From this point, however, the religious chasm could not be so easily exploited. Geoffrey deals with the difficulty by a drastic rewriting of Bede's account. ${ }^{50}$ The actual conversion of the English is dealt with as summarily as possible, and then the narrative moves immediately to the British church and its relations with the missionary who came to the English, Augustine. Bede had condemned the Britons for refusing to help Augustine to evangelize the English, and later, when many British monks of Bangor are slaughtered by the pagan Æthelfrith of Northumbria, Bede portrayed this as no more than divine justice. Contrast Geoffrey here: in his account, Augustine finds the British church to be flourishing, correctly organized, and distinguished by great sanctity. Augustine is not allowed any dialogue: all the talking is done by Abbot Dinoot of Bangor. The Britons' refusal to help in

$47 \quad D G B$, ix.147.94-105.

$48 D G B$, ix.147.110: "ipsum in memoria ipsius saepissime reuocabat".

$49 D G B$, xi.188.178-8o: "in parte autem Britonum adhuc uigebat Christianitas, quae a tempore Eleutherii papae habita numquam inter eos defecerat", "It [Christianity] still flourished in the British part, never having wavered since it was introduced in pope Eleutherius' time."

50 Compare $D G B$, xi.188-89 with Bede, Ecclesiastical History ii.2, ed. and trans. Colgrave and Mynors, pp. 134-43. Wright, "Geoffrey of Monmouth and Bede", pp. 35-41, gives a detailed comparison and very lucidly reveals Geoffrey's pro-British bias. See further M.J. Curley, Geoffrey of Monmouth (Twayne's English Authors Series, 509), New York, 1994, pp. 102-o8. This episode is also discussed by Rebecca Thomas in her contribution to this volume. 
the conversion of the Saxons is explained on the reasonable basis that the latter were mortal enemies who were occupying most of their land. The killing of the British monks is martyrdom and they "won their place in the kingdom of heaven". ${ }^{11}$ Finally, the massacre of the monks is avenged by a wholly fictitious British victory over the Saxon army.

A further difficult matter which Geoffrey inherited from Bede was the career of the Christian king of Northumbria, Oswald. ${ }^{52}$ In Bede's account, the Welsh king Cadwallon of Gwynedd attacked Northumbria, killed its king Edwin and ravaged the kingdom sorely. He was met in battle at Denisesburn by Oswald, and fell (c.633). Some years later (642), Oswald himself was killed in another battle by King Penda of Mercia. Bede presented Oswald in strongly hagiographical terms: his victory is won under the sign of the Cross and through trust in God, whereas his British opponent Cadwallon was denigrated as a Christian in name only. Oswald was a famous and widely venerated saint, and it would appear that Geoffrey was unable or unwilling to eliminate Bede's positive, hagiographical portrait of him. ${ }^{53}$ Geoffrey's expedient was to remove his hero Caduallo from the battle altogether. Making clever use of the information which he found in Bede, who said that Cadwallon allied himself with Penda of Mercia, Geoffrey made Penda into the opponent whom Oswald defeated. Instead of falling in battle against the English king, Caduallo dies in his bed after a long and glorious reign. Penda, meanwhile, fights Oswald a second time and kills him; again, Geoffrey makes sure to state that Caduallo was elsewhere. If the English saint could not be eliminated, his opponent could still be rescued from the role of villain in Oswald's hagiography.

\section{$5 \quad$ Saints, Churchmen, and Monks}

Geoffrey's history concentrates on kings and military leaders, and this is an important part of the secularism which critics have attributed to him. Bishops appear largely as adjuncts to kings, though Guithelinus, Germanus, and Dubricius have some important agency of their own. Guithelinus and Dubricius, especially, are fighting prelates, but even their role is largely that of inserting some

\footnotetext{
$51 \quad D G B$, xi.189.210: "martirio decorati regni caelestis adepti sunt sedem."

$5^{2} D G B$, xi.199; contrast Bede, Ecclesiastical History ii.2o and iii.1-2, ed. and trans. Colgrave and Mynors, pp. 202-07 and 212-19.

53 Cf. N. Wright, "Geoffrey of Monmouth and Bede", $A L 6$ (1986), 27-59, at p. 43. He suggests that Geoffrey retained Oswald's saintly characteristics as a "foil" for the later British saint Cadwaladr. It is more likely that Oswald was simply so well-established as a saint that he had to be accommodated.
} 
backbone into the secular power when it seems to be fainéant. Dubricius, the Welsh Dyfrig, seems to have inherited the role of St Germanus as war-leader of the Britons against the pagans, for his harangue of the British army before Badon recalls the role of Germanus in the famous Alleluia victory. ${ }^{54}$ The message, however, is notably different. The hagiographical picture of Germanus allows no room for any other agency than God working through the saint, and so the pagan army turns and flees without a drop of blood being spilt. Geoffrey's Dubricius, in contrast, urges the Britons to fight to the last extremity, and they do. The saint's part in the battle is limited to exhortation. The victory, it should be noted, is still God's: the tide of battle only turns in the Britons' favor when Arthur invokes the names of the Virgin Mary and then God himself, at which point he becomes irresistibly powerful. ${ }^{55}$ Yet the battle was won through the courage and valor of God's servants, not by a miracle.

No other saint in Geoffrey's $D G B$ quite matches Dubricius. Eldadus, bishop of Gloucester, is described as beatus and as a man of the greatest wisdom and devotion. ${ }^{56} \mathrm{He}$ buries the dead British leaders after the treachery of the long knives, attends the council of Aurelius Ambrosius, makes a speech which ensures that the Saxon leader Hengist is executed and another which secures mercy for the remaining Saxons, and finally escorts Aurelius to the burial place of the British leaders at Ambrius's monastery. ${ }^{57}$ Eldadus is Geoffrey's own invention, as Tatlock showed. ${ }^{58}$ His connection with Gloucester plausibly reflects Geoffrey's hopes for the patronage of Robert, earl of Gloucester. Another quite prominent saint is David, who succeeds Dubricius at Caerleon. Uncle of Arthur, teacher and leader of an exemplary life, he dies in the reign of Constantinus, in Menevia (now St Davids), a monastery of his own within his diocese. ${ }^{59}$ He loved Menevia because it had been founded by Patrick, who prophesied his birth. There, too, he was buried at the order of King Maelgwn. As was noted earlier, some of this material diverges from the traditions of

$54 D G B$, ix.147; cf. Bede, Ecclesiastical History i.2o, ed. and trans. Colgrave and Mynors, pp. 62-65. Geoffrey omits all mention of the Alleluia victory from the $D G B$.

$D G B$, ix.147.126-28: "Quemcumque attingebat Deum inuocando solo ictu perimebat, nec requieuit impetum suum facere donec quadringentos septuaginta uiros solo Caliburno gladio peremit", "As he called on God, he killed any man he touched with a single blow and pressed forward until with Caliburnus alone he had laid low four hundred and seventy men."

$56 \quad D G B$, viii.125.159.

$57 \quad D G B$, viii.104.470-73, 125.162-66, 126.182-86, 127.204.

58 Tatlock, $L H B$, p. 242.

$59 \quad D G B$, ix.158.405-06 and xi.179.89-94. 
St Davids itself. In Rhygyfarch's Life of St David, Patrick relinquishes the site to David, to whom is reserved the honor of founding the church. ${ }^{60}$

David, the exemplary monk-archbishop, reminds us that the $D G B$ offers no real evidence of hostility to monks or monasticism. The reminder is needed, for it has been argued that Geoffrey wrote in a spirit of secular distrust for cloistered monks. ${ }^{61}$ It should be noted that "devout [religiosi] communities of men and women [who] serve God according to the Christian tradition" are cited as a praiseworthy feature of Britain's great cities, while the monks of Bangor are praised for their devotion and for sustaining themselves through their own labors. ${ }^{62}$ True, the monk Constans makes a terrible king, being entirely unprepared for rule on account of his cloistered life, ${ }^{63}$ but that is not a criticism of monasticism in itself but of the breaking of monastic vows. The last British king, Cadualadrus, renounces the world to die as a penitent. ${ }^{64}$

In Geoffrey of Monmouth's view of history it is rulers, rather than churchmen, who dominate events. Yet if history is rooted in this world, it is still written with an acceptance that secular rulers, too, have to look forward to the next world. This will become particularly apparent in the last two sections of this essay, which are devoted to how Geoffrey ended his history and to the rethinking of his great work which he undertook in the later $V M$.

\section{The Ending of British Rule and the Hope for a Future Restoration}

As we approach the end of the $D G B$, so the tone becomes more and more colored by the kind of providential history that Geoffrey is supposed by many modern commentators to have left behind. A long speech by Caduallo injects a tone of moral judgement into this final section of the book. ${ }^{65}$ Addressing Salomon of Brittany, Caduallo blames the weakness of his own people on their degeneracy. His speech is an adaptation of Gildas's powerful diatribe against the sins of the Britons. Indeed, Caduallo mentions Gildas by name, and unusually among Geoffrey's appeals to that author, the citation is honest. The subsequent loss of much of Britain is in accordance with the will of God. Caduallo, however, is not prepared to abandon the fight. He still believes that God's

\footnotetext{
6o Rhygyfarch, Life of St David §3 and §15, ed. Sharpe and Davies, pp. 110-13 and 120-21.

61 E.g. V.I.J. Flint, "The Historia Regum Britanniae of Geoffrey of Monmouth: Parody and its Purpose. A Suggestion", Speculum 54:3 (1979), 447-68.

$62 \quad D G B$, i. $5.40-42 ;$ xi.188.180-87.

$63 D G B$, vi.95.168-69.

$64 \quad D G B$, xi.206.583.

$65 \quad D G B$, xi.195.
} 
favor can be turned back to the Britons if they fight bravely and nobly for their country, and even if not, the reputation of the Britons should still be saved by the bravery of their resistance. Here we see the contradictory tendencies in Geoffrey: on the one hand the Gildasian inheritance of sin and repentance, but on the other the aristocratic values of courage and glory. No resolution is offered: Caduallo embarks on his war of reconquest, and is spectacularly successful. Yet he manages only to stave off defeat, not to prevent it altogether. Under his successor, Cadualadrus, the Britons are finally deprived of the sovereignty of Britain by the will of God, which is visited upon them in the shape of plague and famine; no military power, insists Geoffrey, could have prevailed over them in this way, but against the will of God there can be no victory. They themselves are to blame for their plight, which is a punishment for their many great sins. The Saxons, however, are only able finally to occupy what is now England because all of its British inhabitants have abandoned it for fear of the anger of God. It is left to Cadualadrus, last British king of Britain, in another of the great speeches from Book XI, to tell his fellow-countrymen that they have lost their age-old battle:

Woe to us sinners for the terrible crimes with which we never ceased to offend God when we had time to repent. His mighty retribution is upon us, to uproot from our native soil us whom neither the Romans once nor later the Scots, the Picts or the deceitful treachery of the Saxons could drive out. In vain have we so often recovered our native land from them, since it was not God's will that we should reign there for ever. ${ }^{66}$

It is difficult to see how else Geoffrey could have handled this crucial moment of the loss of sovereignty. Throughout the $D G B$, the Britons are portrayed as formidable warriors. Again and again, they prevail against invaders and conquer foreign lands. Geoffrey has repeatedly postponed the evil moment of their defeat far beyond the point where the preceding English historians had placed it; now, finally, it has to be faced. How could he account for the final loss of Britain without undermining everything he has said so far? His answer is this Gildasian turn which absolves the Britons of failure as warriors and elevates

$66 \quad D G B$, xi.203.532-37: "Vae nobis peccatoribus ob immania scelera nostra quibus Deum offendere nullatenus diffugimus dum paenitentiae spatium habebamus. Incumbit ergo illius potestatis ultio, quae nos ex natali solo extirpat, quos nec Romani nec deinde Scoti uel Picti nec uersutae proditionis Saxones exterminare quiuerunt. Sed in uanum patriam super illos totiens recuperauimus, cum non fuit Dei uoluntas ut in ea perpetue regnaremus." 
their fate to the realm of divine providence, which - so the hope is expressed may in future encompass their restoration.

The close dependency on Gildas in the last part of the $D G B$ has been noted and discussed by Neil Wright. ${ }^{67}$ As he observes, Geoffrey's greater sympathy for the Britons caused him to postpone this kind of rhetoric to a very late stage in his history. The postponement allows for a lengthy development of the Britons' heroic resistance. Nevertheless, the moment of judgement comes, and the Britons are found lacking, as even their leaders can see. It is no coincidence that these purple passages are put into the mouths of characters. The set-piece speech was a convention of historiography inherited from the classical historians, a device that allowed passages of emotionally charged language to be accommodated within the much more neutral style of history. Most of Geoffrey's book is told in the smooth, objective-sounding style of the historian. These dense recapitulations of Gildas's highly-charged rhetoric could only be accommodated as direct speech. The important point, however, is that they are accommodated.

Along with the language of providential history, we find the language of hagiography appearing, too, in the figure of Cadualadrus. Geoffrey's last king of Britain ends his life in Rome as a penitent who had "renounced the world for the sake of the Lord's eternal kingdom". ${ }^{68}$ Cadualadrus is a composite of a king Cadwaladr of Gwynedd and of Bede's Cædwalla, a king of Wessex who died in Rome in 688. The very meager early sources for Cadwaladr of Gwynedd show that his reign was already regarded as historically significant before Geoffrey; in the probably 1oth-century prophetic poem Armes Prydein Vawr ("The Great Prophecy of Britain"), he appears as one of two heroes who will return to lead the Britons to victory. ${ }^{69}$ It seems to have been Geoffrey who turned this hope for Cadwaladr's return into an expectation that his relics would be brought back from Rome: the Cadwaladr of Armes Prydein is a vengeful war leader, not a penitent, and still less a set of bones. This opens the difficult question of whether Cadwaladr was regarded as a saint before Geoffrey. There are several churches called Llangadwaladr in Wales, notably one in Anglesey which contains a memorial to Cadwaladr's grandfather, Cadfan. ${ }^{70}$ Yet, none of the Welsh texts that call him Cadwaladr Fendigaid, "the Blessed", is earlier than Geoffrey, and his credentials as a saint in the $D G B$ appear to rest on his pilgrimage and

67 N. Wright, "Geoffrey of Monmouth and Gildas", $A L 2$ (1982), 1-40, at pp. 12-14, 21, 39-40.

$68 D G B$, xi.206.583: "abiectis mundialibus propter Dominum regnumque perpetuum".

69 See Ben Guy's chapter in this volume.

70 N. Edwards, A Corpus of Early Medieval Inscribed Stones and Stone Sculpture in Wales, 3: North Wales, Cardiff, 2013, pp. 18o-83. 
death in the holy city, features actually taken from the career of Cædwalla of Wessex. Unless the conflation of the two men is older than the $D G B,{ }^{71}$ it would seem that Geoffrey at the very least strengthened the sanctity of Cadwaladr, if he did not reinterpret a wholly secular figure. By accepting the will of God, and renouncing the world, Geoffrey's holy St Cadualadrus brings the story of the Britons to a fitting conclusion. The only remedy for their plight is penance, and their last king shows them the way to redemption. Symbolically, when the time of their penance comes to an end, St Cadualadrus (in the shape of his relics) will again lead them to victory. ${ }^{72}$

The end of Geoffrey's book should warn us against dismissing providential history. Hanning's powerful argument that Geoffrey saw history as a series of cycles of rise and decline, symbolized for him by Fortune's wheel, might lead us to ignore the very deliberate choices made by Geoffrey in this last section. I would not wish to deny that cyclical history governed by fortune is an important concept in the $D G B$, but it does not replace providential history. Rather, both co-exist in an uneasy tension which is not resolved. This difficulty can be seen in Hanning's treatment of the ending. Insisting that the Britons' plight was the result of their own internal strife, he offered a resolutely secular reading which brushed aside the religious language of sin and penitence which is so notable in the $D G B$ from the disastrous reign of Kareticus onwards. His dismissal of the providential turn as a "convenience" on the part of Geoffrey is perhaps the weakest part of his whole argument. ${ }^{73}$ Hanning also underestimated the emotional importance of British identity; indeed, his focus on

71 D.N. Dumville, "Brittany and Armes Prydein Vawr", Études celtiques 20 (1983), 145-59, at p. 154 is open to the idea that the conflation predated Geoffrey, but on the grounds of a doubtful biblical parallel. In Trioedd Ynys Prydein: The Triads of the Island of Britain, ed. and trans. R. Bromwich, 4th ed., Cardiff, 2014, Bromwich also argues that the conflation is old because Bede calls Cadwaladr's father, Cadwallon, by the English form Ccedwalla. That does not show when Cadwaladr himself was confused with Cædwalla of Wessex specifically. Wright, "Geoffrey of Monmouth and Bede", pp. 50-52 tends to see Geoffrey as the originator. As he notes, the conflation can hardly be a blunder.

72 The motif of Cadualadrus's relics is rather reminiscent of the fate of many such relics in the face of violent events like the Scandinavian raids of the 9 th and 1oth centuries: to be withdrawn to a place of safety in the hope that they might one day return in triumph to their proper home. See, for a general discussion, R. Bartlett, Why Can the Dead Do Such Great Things? Saints and Worshippers from the Martyrs to the Reformation, Princeton, 2013, pp. 290-92. Cadualadrus is slightly unusual, though, in making provision for their safety before he actually died.

73 Hanning, Vision, p. 140 and also p. 232, n. 85. His argument that the angelic voice announces just one more stage in the "eternal cycle" of "Fortune's Wheel", rather than having providential meaning, does not convince. The fact that he returns to the problem suggests a continuing difficulty for his interpretation. 
fortune and cyclicality in Geoffrey's thought at times comes close to treating the case of the Britons as no more than an exemplum that could have been replaced by any other. The intensity of Geoffrey's partisanship, revealed in his savage rewriting of Bede, tells another story. Far from secularizing Gildas, as Hanning claims, ${ }^{74}$ Geoffrey in the end finds no alternative to him, for in no other way could the failure of the Britons be explained nor, perhaps, be made emotionally bearable.

\section{Prophecy, History, and the Vita Merlini}

British history, as presented in the $D G B$, is a fulfilment of prophecy. The glorious future of the Britons is foretold to Brutus on Leogetia in Book I, and their rule over Britain ends with another prophecy, that they will recover the island only when God is pleased to allow that to happen. Book VII, the $P M$, which also circulated independently, is given over entirely to prophecies told by Merlin to Vortigern. Initially these cover events in the $D G B$ from the time of Merlin to the end, and then they continue through what can be recognized as oblique references to subsequent Saxon and Norman history, through Geoffrey's own time and beyond, to the moment when British rule over the island would be renewed. Beyond that point, again, they continue in a series of fantastically obscure images, culminating in the disturbance of the stars and planets which will precede the Day of Judgement and the end of time.

Though history and prophecy appear so closely linked in the $D G B$, the nature of prophetic inspiration is not questioned. Brutus is not sure whether to believe that a goddess has indeed spoken to him, ${ }^{75}$ yet the prophecy is clearly fulfilled by subsequent events. Those who witness Merlin's ecstasy believe that "he was inspired" - numen esse in illo - but the source of that inspiration is not stated. ${ }^{76}$ Later, Merlin himself speaks of a spirit who instructs him and would abandon him if he abused the gift for frivolous purposes. ${ }^{77}$ At least the prophecy given to Cadwaladr is unambiguously transmitted by an angelic voice and thus of divine origin. The angel's words are checked against older prophecies by Alanus, ruler of Brittany, and found to be in agreement with them. It has been suggested that this shows a certain skepticism toward the divine origin

\footnotetext{
74 Hanning, Vision, pp. 137-38.

$75 \quad D G B, \mathrm{i} .17 \cdot 313^{-14}$.

$76 \quad D G B$, vi.108.577.

$77 \quad D G B$, viii.128.228-3o.
} 
of the prophecy, ${ }^{78}$ but arguably the opposite is true: the angel's voice is verified as authentic because previous prophecies, too, were believed somehow to come from God. Perhaps the question looms larger for modern readers than for medieval ones. Such has been argued by Julia Crick, who pointed out that 12th-century churchmen were heavily involved with writing and interpreting prophetic texts. ${ }^{79}$ Geoffrey himself tells us that he first "translated" the $P M$ on behalf of Alexander, bishop of Lincoln. That Merlin's vision ends with the eschatology of the Last Judgement is another indication that the prophet spoke in accordance with God. ${ }^{80}$ As Richard Southern pointed out, most medieval commentators were ready to acknowledge that prophetic inspiration, though it originated in God, could be manifested in apparently unworthy or even nonChristian individuals. ${ }^{81}$ Merlin was the son of an incubus, and both Southern and Crick discuss evidence that his nature was a matter of concern for some medieval readers, ${ }^{82}$ but there is nothing in the $D G B$ that requires us to take him as an explicitly pagan prophet.

Geoffrey returned to the figure of the prophet in his later work, the $V M$. This text may not have been as popular or influential as the $D G B$, to judge by the smaller number of surviving manuscript copies, but it should not be neglected. The story is set many decades after the time in which Merlin was active according to the $D G B$, and thus Merlin's lifespan is greatly expanded. Here, he is a Welsh king and prophet who fights in a battle in northern Britain and goes

78 Curley, Geoffrey of Monmouth, p. 107.

79 J. Crick, "Geoffrey of Monmouth, Prophecy and History", Journal of Medieval History 18:4 (1992), 357-71 traces the reception of the prophecies; see also her "Geoffrey and the Prophetic Tradition", in S. Echard (ed.), The Arthur of Medieval Latin Literature: The Development and Dissemination of the Arthurian Legend in Medieval Latin (Arthurian Literature of the Middle Ages, 6), Cardiff, 2011, pp. 67-82.

8o Hanning, Vision, pp. 171-72 interprets this quite differently, seeing "no divine providence, no judgement"; "the impersonal universe ... will lose control of itself and history will dissolve into nothingness." Yet Merlin refers quite clearly to the resurrection of the dead, which in Christian belief will precede Judgement.

81 R.W. Southern, "Aspects of the European Tradition of Historical Writing, 3: History as Prophecy", Transactions of the Royal Historical Society, fifth series, 22 (1972), 159-8o (repr. in R.J. Bartlett (ed.), History and Historians: Selected Papers of R.W. Southern, Oxford, 2004, 48-65, at pp. 49, 54-56).

82 Southern, "Aspects of the European Tradition of Historical Writing, 3", pp. 55-56; Crick, "Geoffrey of Monmouth, Prophecy and History", esp. pp. 358, 362, 37o. The commentary on the prophecies attributed to Alan admits that some people worried that Merlin was a pagan, and cites the Lucius legend to show that he must, as a Briton, have been a Christian (Alan of Lille, Interpretation of the Prophecy of Merlin, ed. Ioachim Bratheringii, Prophetia anglicana: Merlini Ambrosii britanni ... vaticinia et praedictiones a Galfredo Monemutensi latine conversae una cum septem libris explanationum in eamdem prophetiam ..., Frankfurt, $16 \circ 3$ and 16o8, pp. 4-5). 
mad with grief. He spends many years living as a wild man in the wilderness of what is now south-west Scotland and north-west England. Twice he is temporarily cured, but twice he suffers a relapse. Finally, he recovers his senses after drinking from a spring of pure water. This leads to the loss of his prophetic spirit, which passes to his sister Ganieda. The work ends with Merlin, Ganieda, the poet Telgesinus, and another former madman, Maeldinus, all abandoning the world to live together as hermits in the wilderness.

The $V M$ appears a rather disjointed poem, but if it is seen as a reconsideration of Geoffrey's earlier work, then its force becomes more apparent. The $D G B$ shows the great sweep of history, the rise and fall of peoples and dynasties. The scale of the $V M$ is smaller. Most of its action takes place during the short reign of the usurper Conanus, at a time when the fortune of the Britons is at a low ebb. Though Merlin briefly prophesies the restoration of British power, the focus is very much on political and moral failure, on a kingdom brought low by internecine strife. The parallel with Geoffrey's own time is apparent, for the $V M$ was composed during the civil war that erupted after the death of Henry I in 1135. Events in that war are foretold by Ganieda at the end of the poem. The $V M$ is a study in personal and religious retreat. It follows Merlin into the wilderness, and comes to the conclusion that life is preferable there. In marked contrast to the $D G B$, the $V M$ relegates the world of kings and battles to the background. The response of the individual to events is the theme here: the political consequences of the battle are ignored in favor of Merlin's overwhelming grief for his fallen brothers, with which we may compare Ganieda's sadness after the passing of King Rodarchus. Ultimately, the individual's best response to the transience of worldly life is to retreat into a closer relationship with God. Merlin, having previously been compelled into the wilderness by his madness, rationally chooses the ascetic life, refusing the chance to take up his kingship again. The other madman, Maeldinus, is cured by the same spring as Merlin, and makes the same choice. Ganieda joins her brother after the death of her husband, King Rodarchus; her lament for him is full of the topoi of renunciation of the world. ${ }^{83}$ Telgesinus, finally, abandons what I take to be his secular verse to live under Merlin's guidance. ${ }^{84}$ Though it may seem that the four retreat into a small world of their own, the long discourses of Telgesinus and Merlin on creation set their decision in a much broader context, sub specie

$83 \quad V M$, ll. 693-731.

$84 V M$, l. 1458: "despecto themate mundi"; Clarke's translation, "turning away from the traffic of the world", is too general given Taliesin's role as a poet; I suggest "turning away from the [poetic] theme of this world". 
aeternitatis. They choose the life to come over the disappointments and failures of this life.

Though the $V M$ explores the complexity of the prophetic role to much greater degree than the $D G B$, it remains ambiguous regarding Merlin's inspiration. This seems to accompany his loss of reason, and yet he is specifically called a vates even before the fateful battle. This Latin term for a poet always implies a figure who has access to higher or divine inspiration. Moreover, Merlin welcomes the return of his reason, even though the price he must pay is the loss of his prophetic gift, and he thanks God for granting him the change, as if his former state were not so much a gift as a burden. ${ }^{85}$ Yet having regained his reason, Merlin promptly chooses to remain in the wilderness as a hermit. Merlin's remarkable knowledge of birds is gained (so he claims) while he lives as a wild man, yet Telgesinus's equally thorough knowledge of creation and geography derives from study, probably under his master Gildas in Brittany, and so the relative merits of reason and inspiration are left unstated. ${ }^{86}$ Ziolkowski has suggested that this reflects the incomplete amalgamation of contradictory traditions - a shamanism which he attributes to Celtic tradition, political prophecy, and the idea of Christian prophecy - but he also tries to argue that Merlin progresses from one to the next, from an initial state of faithlessness to an acceptance of Christian revelation. ${ }^{87}$ Yet Merlin is clearly a Christian from the beginning, ${ }^{88}$ and it is possible to see the different sources of knowledge, namely inspiration and the scholarly study of creation, as complementary rather than opposed to one another. Merlin begins not in a state of faithlessness, but in an attachment to worldliness which is overcome by the end of the poem. ${ }^{89}$

Geoffrey's portrait of Merlin in the $V M$ bears strong resemblances to the northern wild man, Lailoken, known from Scottish sources. It has been plausibly argued that Geoffrey appropriated the Lailoken figure and re-identified

$85 \quad V M, 11.1156-75$.

$86 V M$, ll. 1298-1386 (Merlin on birds), 737-940 (Telgesinus on creation, waters, and islands), 1179-1253 (on waters again); for Telgesinus studying under Gildas, see ll. 685-88.

87 J. Ziolkowski, "The Nature of Prophecy in Geoffrey of Monmouth's Vita Merlini", in J.L. Kugel (ed.), Poetry and Prophecy: The Beginnings of a Literary Tradition, Ithaca, 199o, pp. 151-62.

88 Cf. his invocation of Christ in $V M, 1.87$.

89 For an interpretation on these lines, see P.B.R. Doob, Nebuchadnezzar's Children: Conventions of Madness in Middle English Literature, New Haven, 1974, pp. 153-58. Echard, Arthurian Narrative in the Latin Tradition, pp. 214-31 offers a very different reading of the $V M$ as "an almost nihilistic appraisal of the abilities of man to understand or control his destiny". 
him with his southern Welsh prophet. ${ }^{90}$ Lailoken was associated with the patron saint of Glasgow, St Kentigern, from whom he receives the sacrament just before his death. Kentigern was also the supposed founder of the see of St Asaph in north-east Wales, to which Geoffrey was elected bishop in 1151. It is tempting to make some connection between this fact and his reception of the northern material, for Geoffrey may have come across the wild man material while researching the career of Kentigern. However, there is such a dearth of early sources from St Asaph that it is impossible to establish whether the cult of Kentigern was present there in Geoffrey's time. Indeed, an alternative and very plausible suggestion is that Geoffrey himself was responsible for introducing the cult of Kentigern to St Asaph. ${ }^{91}$ Certainly the connection of the Glasgow saint with north-east Wales seems fanciful enough to be the product of his imagination: compare his removal of Dubricius and David from their acknowledged churches to his imaginary see of Caerleon. If, as seems likely, the material on the northern wild man came to him already attached to traditions of St Kentigern, it is notable that Geoffrey has completely excised the saint from the narrative. ${ }^{92}$ In choosing to close his poem with Merlin's embrace of the hermit life rather than his death, Geoffrey left no room for the saint in reconciling the wild man to reason and salvation. Perhaps, as is hinted, a prophet needed no mediator with God. ${ }^{93}$

Some readings of Geoffrey of Monmouth come close to regarding him as entirely detached from the religious culture of his day. Robert Hanning made

90 Most thoroughly by O.J. Padel, "Geoffrey of Monmouth and the Development of the Merlin Legend", cMCS 51 (2006), 37-65. But see also N. Tolstoy, "Geoffrey of Monmouth and the Merlin Legend", $A L 25$ (2008), 1-42, reasserting the view that Myrddin was already a northern figure in Welsh tradition before Geoffrey.

91 Clarke in VM, pp. 33-34; in more detail J.R. Davies, "Bishop Kentigern among the Britons", in S. Boardman, J.R. Davies, and E. Williamson (eds.), Saints' Cults in the Celtic World (Studies in Celtic History, 25), Woodbridge, 20o9, pp. 67-99, at pp. 85-87.

Clarke believed that Kentigern is mentioned obliquely in the elegy for King Rodarchus in $V M$, ll. 698-99: "Tractabat sanctum justo moderamine clerum, / jure regi populos summos humilesque sinebat", which he translated as "He treated the holy priest with due consideration and made the rule of law available to high and low alike." The interpretation of sanctum ... clerum as "holy priest" is forced. It is more likely to be a reference to the clergy in general, see also other examples of the combination of clerus and populus in 1l. 11, 1059, 1082.

93 Cf. $V M$, 1l. 1156-75, where Merlin gives thanks to God for curing him. 
him an intellectual revolutionary who developed the secularizing trend in 12th-century historiography to the furthest extreme imaginable. Christopher Brooke, influenced by Hanning's secularizing approach, saw in Geoffrey's works only humor and the desire for personal advancement, not the serious pursuit of an idea, while more recently Siân Echard seems poised between seeing Geoffrey as either a philosophical or a literary revolutionary. ${ }^{94}$ We should beware, however, the danger of considering British history as little more than a vehicle through which Geoffrey expressed his philosophy or, alternatively, an object upon which he exercised his literary playfulness. That does not do justice to the intensely partisan manner in which Geoffrey refashioned his sources, nor to the pervasive religious element in his works. I have argued, instead, that Geoffrey presents the fate of the Britons in moral, exemplary terms, and that he treats their rise, fall, and future return to power as part of the inscrutable providence of God. This consideration should also weigh on any political interpretation. That Geoffrey could be critical of the Britons, and especially of the Welsh, needs to be seen in the light of the exemplary function of history and the concepts of sin, repentance, and redemption. Geoffrey was not a modern nationalist, concerned to whitewash every blemish. National history could not be divorced from salvation history, nor from the reality of human weakness. British defeat was a fact which demanded an interpretation in moral terms, but the $P M$ left open the possibility that the Britons would recover from their state of sin and be allowed once again to rule their own island. History, of course, would not end at that point, and neither did Merlin's prophecies: there would still be sin, and change, and tumult, until all would be resolved in Judgement. If Geoffrey struggled to resolve the tension between the providential model and the fickleness of events in this world, it may be suggested that his $V M$ offers trust in God as his response.

94 Compare Echard, Arthurian Narrative in the Latin Tradition, ch. 1 with her "'Hic est Artur': Reading Latin and Reading Arthur", in A. Lupack (ed.), New Directions in Arthurian Studies, Cambridge, 2002, pp. 49-67. 